\title{
As religiões afro-brasileiras e seus seguidores
}

Reginaldo Prandi

\section{Religião declarada}

Na última década, muita coisa mudou também no âmbito das religiões no Brasil. O censo de 2000 nos diz que o País está hoje menos católico, mais evangélico e menos afro-brasileiro. Velhas tendências foram confirmadas, novas direções vão se impondo. Religiões recém-criadas se enfrentam com as mais antigas, velhas religiões assumem novas formas e veiculam renovados conteúdos para enfrentar a concorrência mais acirrada no mercado religioso. Vou tratar aqui de um ramo religioso pequeno demograficamente, porém importante do ponto de vista de seu significado

\footnotetext{
${ }^{1}$ Livre-docente e doutor em Sociologia pela USP, onde é professor titular; autor, entre outros livros, de Os candomblés de São Paulo (Hucitec, 1991), A realidade social das religiões no Brasil (com Antônio Flávio Pierucci, Hucitec, 1996), Herdeiras do Axé (Hucitec, 1996), Um sopro do Espírito (Edusp, 1997), Mitologia dos orixás (Companhia das Letras, 2000), Encantaria brasileira (organizador, Pallas, 2001), Os príncipes do destino (Cosac \& Naify, 2001), Ifá, o Adivinho (Companhia das Letrinhas, 2002), Xangô, o Trovão (Companhia das Letrinhas, 2003). Endereço: rprandi@usp.br.
} 
para a cultura brasileira e da visibilidade que transborda de seu universo de seguidores: as religiões afro-brasileiras.

Antes de mais nada é preciso observar que, no caso das religiões afrobrasileiras, o censo oferece sempre cifras subestimadas de seus seguidores. Isso se deve às circunstâncias históricas nas quais essas religiões se constituíram no Brasil e ao seu caráter sincrético daí decorrente. As religiões afro-brasileiras mais antigas foram formadas no século XIX, quando o catolicismo era a única religião tolerada no País e a fonte básica de legitimidade social. Para se viver no Brasil, mesmo sendo escravo, e principalmente depois, sendo negro livre, era indispensável antes de mais nada ser católico. Por isso, os negros que recriaram no Brasil as religiões africanas dos orixás, voduns e inquices se diziam católicos e se comportavam como tais. Além dos rituais de seu ancestrais, freqüentavam também os ritos católicos. Continuaram sendo e se dizendo católicos, mesmo com o advento da República, quando o catolicismo perdeu a condição de religião oficial.

Desde o início as religiões afro-brasileiras se fizeram sincréticas, estabelecendo paralelismos entre divindades africanas e santos católicos, adotando o calendário de festas do catolicismo, valorizando a frequiência aos ritos e sacramentos da igreja. Assim aconteceu com o candomblé da Bahia, o xangô de Pernambuco, o tambor-de-mina do Maranhão, o batuque do Rio Grande do Sul e outras denominações, todas elas arroladas pelo censo do IBGE sob o nome único e mais conhecido: candomblé. Até recentemente essas religiões eram proibidas e por isso duramente perseguidas por órgãos oficiais. Continuam a sofrer agressões, hoje menos da polícia e mais de seus rivais pentecostais, e seguem sob forte precon-ceito, o mesmo preconceito que se volta contra os negros independentemente de religião. Por tudo isso, é muito comum, mesmo atualmente, quando a liberdade de escolha religiosa já faz parte da vida brasileira, muitos seguidores das religiões afro-brasileiras ainda se declararem catolicos, embora sempre haja uma boa parte que declara seguir a religião afro-brasileira que de fato professa. Isso faz com que as religiões afro-brasileiras apareçam subestimadas nos censos, em que o quesito religião só pode ser pesquisado de modo superficial. Com o tempo, as religiões afro-brasileiras tradicionais se espalharam pelo Brasil todo, passando por muitas inovações, mas quanto mais tradicionais os redutos pesquisados, mais os afro-brasileiros continuam se declarando, e se sentindo, católicos. Mais perto da tradição, mais católico. Um mapeamento dos afro-brasileiros segundo as diferentes regiões mostra isso muito bem: eles são em número relativamente pequeno no Nordeste, região em que a religião afro-brasileira tradicional se formou, o que pode parecer paradoxal, e em número bem maior nas regiões em que se instalou mais recentemente, 
ou seja, já no século XX, e onde a mudança religiosa no campo afrobrasileiro tem se mostrado mais vigorosa, casos do Sudeste e do Sul. Até hoje o catolicismo é uma máscara usada pelas religiões afro-brasileiras, máscara que evidentemente as esconde também dos recenseamentos.

Um outro ramo afro-brasileiro, a umbanda, formada no século XX, no Sudeste, é igualmente problemática quando se trata de quantificar seus seguidores. Ela é uma síntese do antigo candomblé da Bahia, que foi transplantado para o Rio de Janeiro na passagem do século XIX para o XX, com o espiritismo kardecista, chegado da França no final do século XIX. No início a nova religião se denominou espiritismo de umbanda, mais tarde, umbanda. Não é incomum, ainda atualmente, os umbandistas se chamarem de espíritas. E também de católicos. O próprio catolicismo, durante anos e anos de propaganda contra a umbanda, a chamava de baixo espiritismo, para diferenciá-la do espiritismo kardecista, que combatia com o mesmo zelo. A umbanda conservou do candomblé o sincretismo católico: mais que isto, assimilou preces, devoções e valores católicos que não fazem parte do universo do candomblé. Na sua constituição interna, a umbanda é muito mais sincrética que o candomblé.

Assim, sempre que se usam dados dos censos sabemos que boa parte dos afro-brasileiros está escondida nas rubricas "católico" e "espírita". Há muito os sociólogos conhecem essa dificuldade (Camargo, 1961). Era de se esperar, contudo, que o novo clima de liberdade religiosa que se respira cada vez mais entre nós, assim como inovações introduzidas por recentes movimentos de africanização e dessincretização das religiões afro-brasileiras, contribuíssem no sentido de tornar a dupla identidade religiosa sincrética menos freqüente. Muitas lideranças afro-brasileiras têm de fato se empenhado em lutar pelo apagamento das vinculações identitárias do candomblé e da umbanda com o catolicismo e o espiritismo.

\section{Contando os seguidores}

Os dados dos censos, inclusive deste último, não são, como já disse, suficientemente fidedignos no sentido de precisar quantos são os afrobrasileiros. Pesquisas feitas com metodologia mais precisa indicam valores maiores, da ordem de pelo menos o dobro das cifras encontradas pelo censo (Pierucci e Prandi, 1996). Assim, não dá para se usar o censo para dizer em que lugar é maior ou menor o número real de afro-brasileiros, pois diferenças observadas podem simplesmente resultar do fato de que numa região os afro-brasileiros declaram mais freqüentemente que noutras sua identidade religiosa sem o disfarce católico ou espírita. 
O censo, entretanto, nos permite comparações ao longo do tempo muito importantes para entendermos o que se passa com essas religiões, pois em cada região a subestimação pode ser considerada característica local, como uma constante preservada ao longo do tempo. Devemos estar atentos para a situação em que de um censo para outro se registra um aumento no número de seguidores declarados: pode de fato ter havido um acréscimo no número de filiados, como pode ter ocorrido um aumento nas declarações em conseqüência de mudança na identidade religiosa que leva o afro-brasileiro a se declarar como tal. Claro que o crescimento das declarações numa região em que a religião foi introduzida recentemente deve apontar para um crescimento real. Já um decréscimo no número de fiéis dificilmente deve refletir maiores dificuldades de alguém se declarar adepto da umbanda ou do candomblé, uma vez que, como já foi enfatizado, tem sido crescente a legitimidade social da livre escolha da religião, sem os constrangimentos tradicionais. Neste caso, um decréscimo no número dos declarados deve mesmo significar uma queda demográfica real. De todo modo, quando tomamos estatísticas para o Brasil como um todo e as comparamos em diferentes épocas, as distorções introduzidas pelos padrões culturais locais e regionais associados com a identidade religiosa acabam se compensando.

Feitas essas ressalvas, o que os dados disponíveis nos mostram é que o conjunto das religiões afro-brasileiras vem perdendo adeptos nos últimos vinte anos. Considerando que atualmente são menos imperativas as razões que têm levado os afro-brasileiros a se declararem católicos ou espíritas, a queda recentemente observada pode até mesmo ser maior, uma vez que em censos anteriores as taxas de "escondidos" podiam ser maiores que as de agora, já que agora estariam menos subestimados.

Conforme mostra a Tabela 1, o pequeno contingente de afro-brasileiros declarados representava em 1980 apenas $0,6 \%$ da população brasileira residente. Em 1991 eles eram 0,4\% e agora, em 2000, são 0,3\%. De 1980 a 1991 os afro-brasileiros perderam 30 mil seguidores declarados, perda que na década seguinte subiu para $71 \mathrm{mil}$. Ou seja, o segmento das religiões afro-brasileiras está em declínio.

Podem ser muitas as razões do descenso afro-brasileiro, mas certamente elas estão associadas às novas condições da expansão das religiões no Brasil no contexto do mercado religioso. A oferta de serviços que a religião é capaz de propiciar aos consumidores religiosos e as estratégias de acessar os consumidores e criar novas necessidades religiosas impõem mudanças que nem sempre religiões mais ajustadas à tradição conseguem assumir. É preciso, sobretudo, enfrentar-se com os concorrentes, atualizar-se. Para reli- 
giões antigas, podem ocorrer mudanças que mobilizam apenas um setor dos líderes e devotos, como, por exemplo, ontem, a fração das Comunidades Eclesiais de Base e, hoje, a parcela da Renovação Carismática do catolicismo (Prandi, 1997). Isso vale para os grandes grupos de religiões congêneres. No caso dos evangélicos, avançam os renovados pentecostais, mas declinam algumas das denominações históricas, tradicionais.

Certamente, o sincretismo católico, que por quase um século serviu de guarida aos afro-brasileiros, não deve mais lhes ser tão confortável. Quando o próprio catolicismo está em declínio, a âncora sincrética católica pode estar pesando desfavoravelmente para os afro-brasileiros, fazendo-os naufragar. Por outro lado, é sabido como muitas igrejas neopentecostais têm crescido às custas das religiões afro-brasileiras, sendo que para uma de suas mais bem-sucedidas versões, a Igreja Universal do Reino de Deus, o ataque sem trégua ao candomblé e à umbanda e a seus deuses e entidades é constitutivo de sua própria identidade (Mariano, 1999).

\section{Tabela 1}

Religiões declaradas nos censos do Brasil em 1980, 1991 e 2000 (população residente)

\begin{tabular}{l|c|c|c}
\hline Religião & $\mathbf{1 9 8 0}$ & $\mathbf{1 9 9 1}$ & $\mathbf{2 0 0 0}$ \\
\hline Católicos & 89,2 & 83,3 & 73,7 \\
\hline Evangélicos & 6,6 & 9,0 & 15,4 \\
\hline Espíritas & 0,7 & 1,1 & 1,4 \\
\hline Afro-brasileiros & 0,6 & 0,4 & 0,3 \\
\hline Outras religiões & 1,3 & 1,4 & 1,8 \\
\hline Sem religião & 1,6 & 4,8 & 7,3 \\
\hline TOTAL (*) & $100,0 \%$ & $100,0 \%$ & $100,0 \%$ \\
\hline
\end{tabular}

(*) Não inclui religião não declarada e não determinada.

Fontes: IBGE, Censos demográficos.

Os afro-brasileiros estão em declínio, mas não é simplesmente isso o que os dados do censo mostram. Se interrompêssemos aqui a análise, muito da dinâmica das religiões afro-brasileiras deixaria de ser entendido.

Para os censos de 1991 e 2000, podemos contar com dados que separam o candomblé e a umbanda, sendo que a classificação candomblé reúne as chamadas religiões afro-brasileiras tradicionais, isto é, as formadas no século XIX (candomblé, xangô, tambor-de-mina, batuque). Pelo menos desde a década de 1950, a umbanda tem sido majoritária no conjunto afro- 
brasileiro. Formada no Rio de Janeiro nos anos 20 e 30 do século XX, logo se espalhou pelo Brasil todo como religião universal sem limites de raça ou etnia, geografia e classe social. Até essa época, o candomblé e as demais denominações tradicionais continuavam circunscritas àquelas áreas urbanas em que se formaram em razão da concentração de populações negras, isto é, aglutinação de descendentes dos antigos escravos africanos. Continuavam a ser religiões de negros. A umbanda não: ela já nasceu num processo de branqueamento e ruptura com símbolos e características africanas, propondo-se como uma religião para todos, capaz mesmo de se mostrar como símbolo de identidade de um País mestiço que então se forjava no Brasil das primeiríssimas décadas do século XX. Alastrou-se rapidamente.

Parecia que a umbanda seria a única grande religião afro-brasileira destinada a se impor como universal e presente em todo o País. E de fato não tardou a se espalhar também por países do Cone Sul e depois mais além. A umbanda é chamada de "a religião brasileira" por excelência, num sincretismo que reúne o catolicismo branco, a tradição dos orixás da vertente negra e símbolos e os espíritos de inspiração indígena, contemplando as três fontes básicas do Brasil mestiço.

Tabela 2

As religiões afro-brasileiras nos censos de 1980, 1991 e 2000

\begin{tabular}{|c|c|c|c|c|c|}
\hline \multirow{2}{*}{ Religião } & \multirow{2}{*}{1980} & \multirow{2}{*}{1991} & \multirow{2}{*}{2000} & \multicolumn{2}{|c|}{ Incremento em \% } \\
\hline & & & & 1980-1991 & 1991-2000 \\
\hline $\begin{array}{l}\text { Religiões } \\
\text { afro- } \\
\text { brasileiras } \\
\text { (candomblé } \\
+ \text { umbanda) } \\
\end{array}$ & $\begin{array}{c}678.714 \\
0,57 \%\end{array}$ & $\begin{array}{c}648.475 \\
0,44 \%\end{array}$ & $\begin{array}{c}571.329 \\
0,34 \%\end{array}$ & $-4,5 \%$ & $-11,9 \%$ \\
\hline Candomblé & $(*)$ & $\begin{array}{c}106.957 \\
0,07 \% \\
\end{array}$ & $\begin{array}{c}139.328 \\
0,08 \% \\
\end{array}$ & $(*)$ & $+31,3 \%$ \\
\hline Umbanda & $(*)$ & $\begin{array}{c}541.518 \\
0,37 \% \\
\end{array}$ & $\begin{array}{c}432.001 \\
0,26 \%\end{array}$ & $(*)$ & $-20,2 \%$ \\
\hline $\begin{array}{l}\text { População } \\
\text { total do } \\
\text { Brasil }\end{array}$ & $\begin{array}{c}119.011 .052 \\
100 \%\end{array}$ & $\begin{array}{c}146.815 .788 \\
100 \%\end{array}$ & $\begin{array}{c}169.799 .170 \\
100 \%\end{array}$ & $+23,4 \%$ & $+15,7$ \\
\hline $\begin{array}{l}\text { Candomblé } \\
\text { sobre o total } \\
\text { de afro- } \\
\text { brasileiros } \\
\text { em \% }\end{array}$ & $(*)$ & $16,5 \%$ & $24,4 \%$ & & \\
\hline
\end{tabular}

Fonte: IBGE, Censos Demográficos. (*) Dado não disponível. 
Mas, a partir da década de 1960 muita coisa mudou nas religiões afrobrasileiras. O candomblé foi extravasando suas fronteiras geográficas, abandonando os limites originais de raça e etnia dos seus fiéis e ampliando seu território. Espalhou-se pelo Brasil, conquistando para seus quadros até mesmo antigos seguidores da umbanda. Nas pegadas da umbanda, também chegou ao estrangeiro. Cada vez mais foi se fazendo visível através da imagem capturada pelas artes e costumes de uma sociedade consumista e multicultural, marcando presença em esferas culturais não religiosas: literatura, cinema, teatro, música, carnaval, televisão, culinária etc.

No interior das religiões afro-brasileiras, o pequeno candomblé foi crescendo. Mostra a Tabela 2 que, em 1991, o candomblé já tinha conquistado $16,5 \%$ dos seguidores das diferentes denominações de origem africana. Em 2000, esse número passou a 24,4\%. O candomblé cresceu para dentro e para fora do universo afro-brasileiro. Seus seguidores declarados eram cerca de 107 mil em 1991 e quase 140 mil em 2000, o que representa um crescimento de $31,3 \%$ num período em que a população brasileira cresceu $15,7 \%$. Sem dúvida um belo crescimento. Por outro lado, a umbanda, que contava com aproximadamente 542 mil devotos declarados em 1991, viu seu contingente reduzido para 432 mil em 2000. Uma perda enorme, de $20,2 \%$. E porque o peso da umbanda é maior que o do candomblé na composição das religiões afro-brasileiras, registrou-se para este conjunto nada mais nada menos que um declínio de 11,9\% numa só década. Na década anterior, fato para o qual Ricardo Mariano chamou a devida atenção (Mariano, 2001), as religiões afro-brasileiras já tinham sofrido uma perda de $4,5 \%$, declínio que não somente se confirmou como se agravou na década seguinte. O conjunto encolheu, mas o candomblé cresceu.

\section{Sincretismo, magia e o enfrentamento com pentecostais}

Como já sabemos, o termo candomblé, como rubrica censitária, inclui diferentes modalidades religiosas afro-brasileiras. Embora as chamemos todas de religiões tradicionais, para contrastar com a umbanda, que é de formação muito mais recente e muito mais desprendida de elementos culturais trazidos da África pelos escravos, elas têm mudado. Mesmo uma religião tradicional muda com o tempo, ao se enfrentar com novas situações sociais, especialmente quando passa a fazer parte, como concorrente, do mercado religioso. $\mathrm{O}$ candomblé tem mudado muito. Transformando-se em religião universal, sem as velhas amarras étnicas que faziam dele religião de 
preservação do patrimônio cultural e fonte de identidade do negro no Brasil, o candomblé pôde se espalhar pelo Brasil.

Em seu processo de transformação em religião universal, isto é, religião que se oferece para todos, o candomblé conheceu o que os sociólogos chamam de movimento de africanização, que implica certas reformas de orientação fortemente intelectual, como o reaprendizado das línguas africanas esquecidas ao longo de um século, a recuperação da mitologia dos deuses africanos, que em parte também se perdeu nesses anos todos de Brasil, e a restauração de cerimoniais africanos (Prandi, 1991). Um elemento importante do movimento de africanização do candomblé e sua constituição como religião autônoma inserida no mercado religioso é o processo de dessincretização, com o abandono de símbolos, práticas e crenças de origem católica. É a descatolização do candomblé, que se descentra do catolicismo e se assume como religião autônoma.

O processo de africanização do candomblé evidentemente é muito desigual e depende das diferentes situações com que se depara aqui e ali. Podemos contudo afirmar com segurança que o candomblé que mais se espalha pelo Brasil, o que mais cresce, é esse que vai cada vez mais deixando de lado as ligações com o catolicismo. Um seguidor desse candomblé pode, se quiser, freqüentar ritos da igreja católica, mas essa participação já não será mais vista como parte do preceito obrigatório a que estavam sujeitos os membros dos candomblés mais antigos; já não é mais um dever ritual. Não é mais necessário mostrar-se católico para poder louvar os deuses africanos, assim como não é mais necessário ser católico para ser brasileiro.

Um seguidor da umbanda está longe dessas preocupações. Ao contrário, ao invés de fortalecer sua identidade religiosa, uma aspiração muito corrente entre os umbandistas é a de se iniciarem também no candomblé. Muitos o fazem e entre esses não são poucos os que acabam abandonando a umbanda definitivamente para se dedicar aos orixás segundo o rito do candomblé. Assim se enfraquece a autonomia umbandista. Nos ritos da umbanda, as preces católicas e a invocação de Jesus, Maria e santos da igreja nas letras dos cantos sagrados continuam indispensáveis. Num hipotético processo de dessincretização da umbanda, grande parte de seu hinário teria que ser abandonada, pois as referências às crenças católicas são muito explícitas.

Umbanda e candomblé são religiões mágicas. Ambas pressupõem o conhecimento e o uso de forças sobrenaturais para intervenção neste mundo, o que privilegia o rito e valoriza o segredo iniciático. Além do sacer- 
dócio religioso, a magia é quase que uma atividade profissional paralela de pais e mães-de-santo, voltada para uma clientela religiosamente alheia à religião africana (Pierucci, 2001). Nesses termos, o candomblé é visto dentro do próprio segmento afro-brasileiro como fonte de maior poder mágico que a umbanda, o que atrai para o seio do candomblé muitos umbandistas. Para o candomblé, que está mais perto do pensamento africano que a umbanda, o bem e o mal não se separam, não são campos distintos. A umbanda, porém, quando se formou, se imaginou também como religião ética, capaz de fazer a distinção entre o bem e o mal, à moda ocidental, cristã. Mas acabou criando para si uma armadilha. Separou o campo do bem do campo do mal. Povoou o primeiro com seus guias de caridade, os caboclos, pretos-velhos e outros espíritos bons, à moda kardecista. Para controlar o segundo, arregimentou um panteão de exus-espíritos e pombagiras, entidades que não se acanham em trabalhar para o mal quando o mal é considerado necessário. Ficou dividida entre dois campos opostos, "entre a cruz e a encruzilhada", na feliz expressão de Lísias Nogueira Negrão (1996).

Tratado durante muito tempo com discrição e segredo, o culto dos exus e pombagiras, identificados erroneamente como figuras diabólicas, veio recentemente a ocupar na umbanda lugar aberto e de realce (Prandi, 1996, cap. 4 ; 2001). Era tudo de que precisava um certo pentecostalismo: agora o diabo estava ali bem à mão, nos terreiros adversários, visível e palpável, pronto para ser humilhado e vencido. O neopentecostalismo leva ao pé da letra a idéia de que o diabo está entre nós, incitando seus seguidores a divisá-lo nos transes rituais dos terreiros. Pastores da Igreja Universal do Reino de Deus, em cerimônias fartamente veiculadas pela televisão, submetem desertores da umbanda e do candomblé, em estado de transe, a rituais de exorcismo, que têm por fim humilhar e escorraçar as entidades espirituais afro-brasileiras incorporadas, que eles consideram manifestações do demônio (Almeida, 1995; Mariano, 1999).

A umbanda e o candomblé, cada qual a seu modo, são bastante valorizados no mercado de serviços mágicos e sempre foi grande - e não necessariamente religiosa - a sua clientela, mas ambos enfrentam hoje a concorrência de incontáveis agências de serviços mágicos e esotéricos de todo tipo e origem, sem falar de outras religiões, que inclusive se apropriam de suas técnicas, sobretudo as oraculares. Concorrem entre si e concorrem com os outros. Por fim foram deixados em paz pela polícia (quase sempre), mas ganharam inimigos muito mais decididos e dispostos a expulsá-los do cenário religioso, contendores que fazem da perseguição às crenças afrobrasileiras um ato de fé, no recinto fechado dos templos como no ilimitado e público espaço da televisão e do rádio. Não foi um ato isolado e gratuito o 
discurso do pastor fluminense Samuel Gonçalves, da Assembléia de Deus, um dos apoiadores do candidato evangélico Anthony Garotinho à presidência da república, em que afirmou que uma das "três maldições" do Brasil é a religião africana (Folha de S. Paulo, 30/07/2002, p. A6). Pouco antes do primeiro turno das eleições presidenciais, o Painel da Folha de $S$. Paulo deu a seguinte notícia, com o intertítulo de Guerra santa: "Panfletos distribuídos por evangélicos reclamam que Brasília 'está se transformando em um terreiro de candomblé', pois estátuas de orixás foram colocadas em um parque. Para mudar isso, diz o documento, só há uma solução: (eleger) Garotinho para presidente e Benedito Domingos (PPB-DF) para governador" (Folha de S. Paulo, 24/09/2002, p. A4). Se se confirma esse novo horizonte político-partidário, em que os evangélicos se fazem presentes até mesmo numa candidatura como a de Lula à presidência da república, na espantosa coligação entre o PT e o PL, em parte controlado pela Igreja Universal do Reino de Deus, não há de ser muito alvissareiro o futuro das religiões afro-brasileiras. Nos tempos atuais, a perseguição sofrida pelas religiões afro-brasileiras passou de órgãos do Estado para instituições da sociedade civil. Pode bem voltar ao Estado, se os governos caírem em mãos religiosas intolerantes?

\section{Organização e concorrência}

Candomblé e umbanda são religiões de pequenos grupos que se congregam em torno de uma mãe ou pai-de-santo, denominando-se terreiro cada um desses grupos. Embora se cultivem relações protocolares de parentesco iniciático entre terreiros, cada um deles é autônomo e auto-suficiente, e não há nenhuma organização institucional eficaz que os unifique ou que permita uma ordenação mínima capaz de estabelecer planos e estratégias comuns na relação da religião afro-brasileira com as outras religiões e o resto da sociedade. As federações de umbanda e candomblé, que supostamente uniriam os terreiros, não funcionam, pois não há autoridade acima do pai ou da mãe-de-santo (Concone e Negrão, 1987). Além disso, os terreiros competem fortemente entre si e os laços de solidariedade entre os diferentes grupos são frágeis e circunstanciais. Não há organização empresarial e não se dispõe de canais eletrônicos de comunicação. Sobretudo, nem o candomblé em suas diferentes denominações nem a umbanda têm quem fale por eles, muito menos quem os defenda. Muito diferente das modernas organizações empresariais das igrejas evangélicas, que usam de técnicas modernas de marketing, que treinam seus pastoresexecutivos para a expansão e prosperidade material das igrejas, que contam 
com canais próprios e alugados de televisão e rádio, e com representação aguerrida nos legislativos municipais, estaduais e federal. Mais que isso, a derrota das religiões afro-brasileiras é item explícito do planejamento expansionista pentecostal: há igrejas evangélicas em que o ataque às religiões afro-brasileiras e a conquista de seus seguidores são práticas exercidas com regularidade e justificadas teolo-gicamente. Por exemplo, na prática expansiva de uma das mais dinâmicas igrejas neopentecostais, fazer fechar o maior número de terreiros de umbanda e candomblé existentes na área em que se instala um novo templo é meta que o pastor tem que cumprir.

Grande parte da fraqueza das religiões afro-brasileiras advém de sua própria constituição como reunião não organizada e dispersa de grupos pequenos e quase domésticos, que são os terreiros. Num passado recente, entre as décadas de 1950 e 1970 , as religiões de conversão se caracterizavam pela formação de pequenas comunidades, em que todos se conheciam e se relacionavam. A religião recriava simbolicamente relações sociais comunitárias que o avanço da industrialização e da urbanização ia deixando de lado. Tanto no terreiro afro-brasileiro como na igreja evangélica, o adepto se sentia parte de um pequeno e bem definido grupo. Ao contrário disso, a religião típica da década de 1980 em diante é uma religião de massa. As reuniões religiosas são realizadas em grandes templos, situados preferencialmente nos lugares de maior fluxo de pessoas, com grande visibilidade, que funcionam o tempo todo - algumas 24 horas - e que reúnem adeptos vindos de todos os lugares da cidade, adeptos que podem freqüentar a cada dia um templo localizado em lugar diferente. Os crentes seguem a religião, mas já não necessariamente se conhecem. $O$ culto também é oferecido dia e noite no rádio e na televisão e o acesso ao discurso religioso é sempre imediato, fácil. Os pastores são treinados para um mesmo tipo de pregação uniforme e imediatista. No catolicismo carismático, por sua vez, a constituição dos pequenos grupos de oração teve que se calçar na criação dos grandes espetáculos de massa das missas dançantes celebradas pelos padres cantores (Souza, 2001). Nesses vinte anos, mudou muito a forma como a religião é oferecida pelos mais bem-sucedidos grupos religiosos. São mudanças a que o candomblé e a umbanda não estão afeitos. Não são capazes de se massificar, mesmo porque a vida religiosa de um afro-brasileiro se pauta principalmente pelo desempenho de papéis sacerdotais dentro de um grupo de características eminentemente familiares. Não é à toa que o grupo de culto é chamado de família-de-santo. Mais que isso: as cerimônias secretas das obrigações e sacrifícios não são abertas sequer a todos os membros de um terreiro, havendo sempre uma seleção baseada nos níveis iniciáticos, não sendo concebível a sua exposição a todos, muito menos sua divulgação por meio televisivo. 
Além de se constituírem em pequenas unidades autônomas, reunindo em geral não mais que 50 membros, os terreiros de candomblé e umbanda usualmente desaparecem com o falecimento da mãe ou pai-de-santo, tanto pelas disputas de sucessão como pelo fato bastante recorrente de que os herdeiros civis da propriedade e demais bens materiais do terreiro, tudo propriedade particular do finado chefe, não se interessam pela continuidade da comunidade religiosa. A não ser em uma dúzia de casas que se transformaram em emblemas de importância regional ou mesmo nacional para a religião, dificilmente um terreiro sobrevive a seu fundador. Tudo sempre começa de novo, pouco se acumula.

Fragmentada em pequenos grupos, fragilizada pela ausência de algum tipo de organização ampla, tendo que carregar o peso do preconceito racial que se transfere do negro para a cultura negra, a religião dos orixás tem poucas chances de se sair melhor na competição - desigual - com outras religiões. Silenciosamente, assistimos hoje a um verdadeiro massacre das religiões afro-brasileiras. Sem um projeto novo de expansão e de reorientação num quadro religioso que se tornou extremamente complexo e competitivo, a umbanda talvez tenha menos recursos que o candomblé para enfrentar a nova conjuntura. Os dados dos censos mostram que é da umbanda que vem o encolhimento demográfico do segmento religioso afrobrasileiro, e o vigor do novo candomblé não tem sido suficiente para compensar as perdas. Nem seus líderes, em grande parte pouco esco-larizados, têm sabido como reagir ou como se organizar, mais preocupados que estão em garantir o funcionamento de seus terreiros. A umbanda tem menos de cem anos de idade e parece não conseguir se adaptar às novas demandas que a sociedade apresenta. Já o candomblé, que é pelo menos um século mais antigo que a umbanda, porém renovado pelas mutações que vem sofrendo em sua expansão, tem se mostrado mais ágil para se adequar aos novos tempos. É mais uma demonstração de que a religião que não muda morre.

De todo modo, a importância cultural da umbanda, do candomblé, do xangô, do tambor-de-mina, do batuque e outras denominações menores no cenário cultural brasileiro tem sido sempre maior que seu alcance demográfico em termos da efetiva filiação de seguidores. Sua contribuição às mais diferentes áreas da cultura brasileira é riquíssima, como acontece também noutros países americanos em que se constituíram religiões de origem negro-africana. Mas, se se confirma que o Brasil vem se tornando religiosamente menos afro-brasileiro, a fonte viva de valores, visões de mundo, arranjos estéticos, aromas, sabores, ritmos etc., que são os terreiros de candomblé e umbanda, pode entrar em processo de extinção. Não seria um 
horizonte promissor para o cultivo da diferença cultural e do pluralismo religioso, cujo alargamento alimentou promessas do final do século XX de mais democracia, diversidade, tolerância e liberdade.

\section{Religião e seguidores em mudança}

Ao longo do processo de mudanças mais geral que orientou a constituição brasileira da religião dos deuses africanos, o culto aos orixás primeiro misturou-se ao culto dos santos católicos para ser brasileiro, forjando-se o sincretismo; depois apagou elementos negros para ser univer-sal e se inserir na sociedade geral, gestando-se a umbanda; finalmente retomou origens negras para transformar também o candomblé em religião para todos, iniciando um processo de africanização e dessincretização para alcançar sua autonomia em relação ao catolicismo. Para isso, certamente, o reconhecimento da cultura dos orixás pela sociedade em geral representa um passo importante e sua divulgação através da música popular, das novelas de televisão e da literatura, entre outras formas de manifestação artística, não deixa de ser um meio muito expressivo.

Nos tempos atuais, as mudanças por que passam as religiões dependem, entre outros motivos, da necessidade da própria religião em mudança de se expandir e se enfrentar de modo competitivo com as demais religiões. Pertencer hoje a uma determinada religião é questão de escolha pessoal. A religião que se professa hoje já não é aquela na qual se nasce, mas a que se escolhe. A religião que alguém elege para si hoje, selecionada de uma pluralidade em permanente expansão, também não é necessariamente mais a que seguirá amanhã. O religioso é agora um ser pouco fiel. Mais de um quarto da população adulta da região metropolitana de São Paulo professa hoje religião diferente daquela em que nasceu, são convertidos, muitos tendo experimentado sucessivas opções (Pierucci e Prandi, 1996).

Houve tempo em que a mudança de religião representava uma ruptura social e cultural, além de ruptura com a própria biografia, com adesão a novos valores, mudança de visão de mundo, adoção de novos modelos de conduta etc. A conversão era um drama, pessoal e familiar, representava uma mudança drástica de vida. $\mathrm{O}$ que significa hoje mudar de religião, quando a mudança religiosa parece não comover ninguém, como se mudar de religião fosse já um direito líquido e certo daquele que se transformou numa espécie de consumidor, consumidor religioso, como já se chamou esse converso? (ibidem) 
As mais díspares religiões, assim, surgem nas biografias dos adeptos como alternativas que se pode pôr de lado facilmente, que se pode abandonar a uma primeira experiência de insatisfação ou desafeto, a uma mínima decepção. São inesgotáveis as possibilidades de opção, intensa a competição entre elas, fraca sua capacidade de dar a última palavra. A religião de hoje é a religião da mudança rápida, da lealdade pequena, do compromisso descartável.

Mas não somente o crente muda de um credo para outro, desta para aquela religião. As religiões mudam também e mudam muito rapidamente, muitas vezes suas transformações apontando para um outro público alvo, visando uma clientela anteriormente fora do alcance de sua mensagem. É verdade que a religião muda a reboque da sociedade, sobretudo no que diz respeito aos modelos de conduta que prega e valores que propaga, freqüentemente adaptando-se a transformações sociais e culturais já plenamente em curso, num esforço para não perder o trem da história, como tem ocorrido especialmente com a igreja católica. Hoje provavelmente muitas das mudanças contemplam não especificamente a sociedade em transformação, mas o conjunto das diferentes religiões que se oferecem como alternativas sacrais, o que significa que a religião muda para poder melhor competir com as outras crenças em termos da adesão de fiéis, e não em razão de se pôr numa posição axiológica mais compatível com os avanços da sociedade, embora isso também possa ser importante e às vezes pressuposto na dinâmica do próprio mercado religioso. Posições anterior-mente alcançadas, tanto no plano da filosofia religiosa como no das consequiências políticas e de orientação na vida cotidiana, que derivam dos valores então assumidos, podem ser completamente abandonadas, com a busca de novos modelos que possam melhor apetrechar aquela religião na concorrência com as demais.

Grupos religiosos, igrejas e denominações cindem-se e se multiplicam, ampliando ainda mais a oferta. Outras apresentam facetas múltiplas, mantendo a unidade institucional, mas sendo capazes de atender a demandas variadas a partir de mensagens diferentes e movimentos particulares, embora gostem de advogar que a diversidade que contemplam e produzem repousa em verdades teológicas únicas. É bastante notória a facilidade com que um adepto do candomblé muda de terreiro, de nação, de grupo religioso, sempre à procura de soluções que acredita poder encontrar fora da comunidade de culto em que se iniciou, trafegando pela enorme variedade de modos de proceder o culto existente no interior do próprio candomblé. Quando não abandona a própria religião para experimentar as mesmas promessas de conforto e felicidade em território pentecostal, por exemplo, o 
que tem sido uma tendência nada desprezível do trânsito religioso brasileiro nas duas ultimas décadas.

Evidentemente, os motivos que reforçam a diversidade religiosa não se encontram somente no âmbito dos crentes seguidores, os consumidores de religião, agindo, sobretudo, no interior da própria organização religiosa. Mudanças internas da religião não significam necessariamente perigo para a sua sobrevivência institucional, não implicam apenas separação e ruptura. Ao contrário, quem não muda não sobrevive. Interesses vários podem então ser exercitados com maior liberdade, numa competição interna cujo sucesso se mede não pelos alcances teológicos possíveis, mas pela adesão de crentes. A própria carreira sacerdotal se vê compelida a incorporar novas habilidades, como aquelas até bem pouco mais apropriadas aos homens de negócios e mais marcadamente atributivas de artistas, ginastas e estrelas de $\mathrm{TV}$, entre outras qualidades. Se isso ocorre em religiões unificadas institucionalmente, pode-se imaginar o que acontece em religiões sem unidade administrativa e doutrinária, como as afro-brasileiras, em que cada terreiro tem para com os demais obrigações apenas protocolares, cada um com seu governo independente.

Mesmo em se tratando de religiões severamente consolidadas em termos de organização sacerdotal e obrigações hierárquicas, surgem novos horizontes de mobilidade social baseada na capacidade pessoal de inovação e empreendimento do sacerdote. Nas grandes igrejas, muitas das quais atuando como conglomerados empresarias de acumulação econômica internacional, assim como nas religiões em que a unidade administrativa e sacerdotal é reduzida, fraca ou inexistente, como ocorre em todo o segmento afro-brasileiro, em certas correntes evangélicas e no conjunto das práticas esotéricas, o sucesso do líder religioso, e por conseguinte da sua religião ou modalidade religiosa, depende da sua capacidade de atrair devotos e clientes e gerar renda necessária à expansão daquela denominação.

Tanta oferta, que é crescente, depende de demanda grande e diversificada. Aquilo que se entende por religião deve contemplar necessidades, gostos e expectativas que escapam às velhas definições da religião, surgindo as mais inusitadas formas de acesso ao sagrado e sua manipulação mágica, como ocorre com muita propriedade no vasto e pouco definido universo do esoterismo.

Experimentar novos sentimentos e formas da religião, contudo, não significa necessariamente mudar de religião. Não é preciso sair da religião que se professa para provar da mudança religiosa. Quantas vezes não ouvimos pessoas mais velhas do candomblé reclamar que sua religião não é 
mais como costumava ser nos seus tempos de juventude? Para os mais velhos, que sentem a mudança como perda, a religião certa é a que não muda. As próprias religiões costumam se apresentar como verdades eternas e imutáveis. "Assim como era no princípio, agora e sempre", afirma o Credo católico, oração afirmativa de uma religião em constante transformação. Os seguidores dos orixás também acreditam na eternidade das verdades religiosas e na perenidade dos ritos. Sabem que muito se perdeu e se modificou ao longo da história do culto dos orixás no Brasil, quer em razão das adversidades sociais e culturais que enfrentou, a começar da própria escravidão, quer por causa da displicência dos sacerdotes mais antigos, que teriam levado para o túmulo muito conhecimento que preferiram não passar adiante. É o que se imagina. Pois bem, esse conhecimento perdido, esquecido, escondido existe em algum lugar, e é imperativo recuperá-lo, para o revigoramento da própria religião e fortalecimento do poder de seus rituais, é o que se acredita.

A idéia de que é preciso recuperar o mistério perdido ao longo da história da religião no Brasil (língua, rezas, cantigas, oriquis, mitos, odus, ebós, tabus etc.) parte do suposto de que em algum lugar existe sobrevivência ou registro do que se perdeu, que alguém de grande conhecimento é capaz de ensinar a fórmula almejada, que algum processo iniciático em outro templo, nação ritualística, cidade ou país pode resgatar o patrimônio que as gerações anteriores de pais e mães-de-santo, por impedimento sóciocultural, egoísmo e desleixo, não souberam transmitir às gerações seguintes. Recobrar segredos guardados é imperativo para restaurar o grande poder mágico da religião. O livro é uma das fontes possíveis, viagens à África e consultas com africanos ou mesmo com velhos sacerdotes brasileiros é outra. Em geral se paga por um segredo guardado, cujo acesso quase sempre depende de submissão a alguma obrigação iniciática. No candomblé, o que é pago é mais valorizado; sem dinheiro não há axé, não há fluxo da força sagrada. Mas a adoção de fórmulas ou elementos recuperados se faz de acordo com a interpretação pessoal, a vontade e o interesse de cada pai ou mãe-de-santo, e se dá de modo diferente em cada terreiro. Assim, recuperar o passado perdido também significa adaptar, inovar, criar.

Uma das mais profundas mudanças observadas no candomblé nas últimas décadas do século $\mathrm{XX}$ foi sua universalização, quando passou de religião étnica a religião de todos, com a incorporação, entre seus seguidores, de novos adeptos de classe média e de origem não africana. Segundo o censo demográfico do IBGE, apenas 16,7\% dos umbandistas se constituíam, no ano 2000, de pessoas que declararam ser de cor preta, cifra que para os dos adeptos do candomblé também foi expressivamente pe- 
quena: $22,8 \%$. Surpreendentemente, o censo de 2000 mostrou também que as religiões afro-brasileiras apresentaram a segunda maior média de anos de escolaridade de seus seguidores declarados, ficando atrás apenas do espiritismo kardecista, religião sabidamene de classe média e de seguidores com escolaridade elevada. Para o ano 2000, a média de anos de escolaridade dos membros declarados do candomblé e da umbanda foi de 7,2 anos, quando a média da população total do Brasil era igual a 5,9 anos, a dos kardecistas 9,6 anos, a dos católicos 5,8 anos e a dos evangélicos pentecostais 5,3 anos.

A base social do candomblé mudou, e mudou muito. Grande parte, talvez a maioria ainda, é de gente pobre, com muitas dificuldades para arcar com os gastos financeiros impostos pela exuberância e complexidade dos ritos, tendo que, além de se reponsabilizar pelas despesas com as oferendas votivas, paramentos, objetos rituais e sua manutenção no terreiro nos períodos de clausura, pagar a "mão de chão", o pagamento feito ao pai ou mãe-de-santo pelo serviço religioso por ocasião das obrigações iniciáticas. Mas a classe média, branca e escolarizada, já está no terreiro, muitas vezes competindo com os negros pobres, que evidentemente, pela sua condição de afro-descendentes, se sentem com freqüência os legítimos donos das tradições dos orixás. Disputam cargos, regalias e posições de mando e de prestígio no intrincado jogo de poder dos terreiros. Levam consigo valores, costumes e aspirações próprios de sua condição social. O hábito de leitura, o gosto pelo estudo, o prazer do consumo descortinam um mundo de novidades a serem buscadas nos livros, nas revistas, na internet, nas atividades universitárias, no mercado de artigos religiosos. No terreiro aprendem o quanto é valorizado o saber religioso. Há tesouros a descobrir em termos da mitologia e dos ritos, segredos perdidos a recuperar. Freqüentemente vem a decepção: os segredos são de polichinelo, acrescentam pouco ou quase nada ao que se sabia e praticava antes. Pior que isso: mais saber religioso não confere necessariamente mais poder, seja o poder de mando seja o de manipulação mágica. A procura, entretanto, não cessa, outros caminhos são buscados.

Nas religiões dos orixás, cada terreiro tem plena autonomia administrativa, ritual e doutrinária, e tudo depende das decisões pessoais da mãe ou pai-de-santo. $\mathrm{O}$ controle social exercido entre terreiros, no conjunto geral do chamado povo-de-santo, se faz por redes informais de comunicação, em que a fofoca ocupa lugar privilegiado (Braga, 1998), sem que a independência do sacerdote-chefe de terreiro, contudo, sofra realmente qualquer limitação eficaz. É costume se dizer que no candomblé "nada pode e tudo pode" e que tabus são para ser quebrados (Augras, 1983). Assim, cada 
comunidade de culto é livre para experimentar inovações ou retornar a formas anteriores, incorporando práticas que para outros da mesma religião podem não fazer o menor sentido. Cada terreiro exerce o direito de copiar e incorporar novidades, mas costuma dotá-las de outros significados. Pode mudar, afirmando que se mantém na rígida tradição. Terreiros nascem uns dos outros, mas não há dois iguais, mesmo quando se observam os terreiros mais antigos, surgidos da mesma matriz fundante.

Os seguidores são unânimes, entretanto, ao acreditar que o futuro da religião depende tanto da manutenção das velhas tradições, das quais os centenários terreiros da Bahia ainda representam a fonte mais legítima, como da recuperação do conhecimento que se perdeu desde que os velhos fundadores foram arrancados de suas famílias e cidades africanas para serem brutalmente escravizados no Brasil. Sempre é tempo de recuperar a tradição que não chegou até o presente, adaptando-a para o presente da religião, pois em algum lugar ainda existe, conforme se crê, muitos segredos guardados.

\section{Referências}

ALMEIDA, Ronaldo Rômulo de. A universalização do Reino de Deus. Dissertação de mestrado em Sociologia. Campinas: Unicamp, 1995.

AUGRAS, Monique. Quizilas e preceitos: trangressão, reparação e organização dinâmica do mundo. In: Carlos Eugênio Marcondes de Moura (Org.). Candomblé desvendando identidades. São Paulo: EMW Editores, 1987.

BRAGA, Júlio. Fuxico de candomblé: estudos afro-brasileiros. Feira de Santana: Universidade Estadual de Feira de Santana, 1998.

CAMARGO, Candido Procopio Ferreira de. Kardecismo e umbanda. São Paulo: Pioneira, 1961.

CONCONE, Maria Helena Villas Boas e NEGRÃO, Lísias Nogueira. Umbanda: da repressão à cooptação. In: Umbanda \& política. Cadernos do Iser, Rio de Janeiro v. 18, 1987.

MARIANO, Ricardo. Neopentecostais. São Paulo: Loyola, 1999.

Análise sociológica do crescimento pentecostal no Brasil. Tese de doutorado em Sociologia. São Paulo, USP, 2001.

NEGRÃO, Lísias Nogueira. Entre a cruz e a encruzilhada. São Paulo: Edusp, 1996.

PIERUCCI, Antônio Flávio. Magia. São Paulo: Publifolha, 2001.

PIERUCCI, Antônio Flávio e PRANDI, Reginaldo. A realidade social das religiões no Brasil.

São Paulo: Hucitec, 1996.

PRANDI, Reginaldo. Os candomblés de São Paulo. São Paulo: Hucitec, 1991.

Herdeiras do axé. São Paulo: Hucitec, 1996.

Um sopro do Espírito. São Paulo: Edusp, 1997. 
Exu, de mensageiro a diabo: sincretismo católico e demonização do orixá Exu. Revista Usp, São Paulo, n. 50, p. 46-65, 2001.

SOUZA, André Ricardo de. Padres cantores, missas dançantes. Dissertação de mestrado em Sociologia. São Paulo, USP, 2001. 